\title{
Sri Lanka's Free Trade Agreements with India and Pakistan: Are They Leading Bilateral Trade Beyond Normalcy?
}

\section{Sirimal Abeyratne*}

\begin{abstract}
Bilateralism arises as a "second-best" option when countries seek benefits beyond those of regional approaches to free trade and those of unilateral liberalization. In spite of the regional initiatives for free trade in South Asia along with policy reforms in individual countries, Sri Lanka entered into bilateral free trade agreements (FTAs) with India (2000) and Pakistan (2005). In a situation where trade within the South Asian region has been sluggish despite higher economic growth, trade liberalization, and regional initiatives for integration and cooperation, this article examines from the Sri Lankan point of view whether the bilateral FTAs have resulted in above-normal trade performance. The analysis suggests that better performance in bilateral trade cannot be attributed exclusively to the success of the FTAs any more than weak performance can be attributed to their shortcomings. Apart from this, merchandise trade does not appear to have performed in isolation as the extent of overall bilateral connectivity set the groundwork for greater integration. The article confirms that bilateral FTAs that seek reciprocity in integration and cooperation are indeed a "second-best" option, compared to the potential trade performance associated with unilateral liberalization in trading partner countries.
\end{abstract}

Keywords: Bilateralism, trade agreements, Pakistan.

JEL Classification: F13, F14, F15, F53.

\section{Introduction}

The paradox of the regional trade and economic growth nexus in South Asia is that, although the region is one of the fastest growing in the world-particularly after the commencement of liberalization policy reforms-intraregional trade does not appear to have performed well (see Abeyratne, 2012; Ahmed, Kelegama, \& Ghani, 2010; Banik \& Gilbert, 2008; Federation of Indian Chambers of Commerce and Industry [FICCI], 2011). Nevertheless, South Asian countries also have over 25 years' history of

\footnotetext{
* Professor of Economics, Department of Economics, University of Colombo, Sri Lanka.
} 
regional initiatives for greater integration and cooperation. The South Asian Association for Regional Cooperation (SAARC) was established in 1985, followed by the implementation of two important regional agreements - the SAARC Preferential Trading Agreement (SAPTA) in 1995 and the South Asian Free Trade Area (SAFTA) in 2005 (Soz \& Srivastava, 2010). ${ }^{1}$ Evidently, the slow progress of the multilateral trade liberalization process under the World Trade Organization (WTO)'s agenda has led to the increasing reliance of countries on regional trade agreements. Additionally, even those countries that considered the progress of regional trade agreements to be too slow have been inclined to enter into bilateral free trade agreements (FTAs).

Given the slow progress of regional initiatives for integration and cooperation, Sri Lanka entered into bilateral FTAs with India and Pakistan. The Indo-Lanka Free Trade Agreement (ILFTA) has been in effect since 2000 and the Pakistan-Lanka Free Trade Agreement (PLFTA) since 2005. ${ }^{2}$ The two agreements left SAFTA redundant with respect to Sri Lanka's merchandise trade with India and Pakistan, preserving its trade with other South Asian countries under SAFTA. Which approach to free trade, among the many alternatives, is likely to yield the best outcome is both a theoretical and empirical issue. The bilateral and regional FTAs that take the reciprocity element into account are actually considered to be "secondbest" options in the absence of unilateral liberalization programs among the trading-partner countries (Krueger, 1997). There are greater possibilities for trade diversion under bilateral or even regional FTAs, and those possibilities could even lead to greater trade distortions when external trade barriers are high.

The purpose of this article is to examine whether Sri Lanka's bilateral FTAs with India and Pakistan have made a difference to the country's normal trade performance. An assessment of bilateral trade performance under bilateral agreements requires an inquiry into merchandise trade within and outside the FTAs, and an analysis of the

\footnotetext{
${ }^{1}$ The Report of the SAARC group of eminent persons, a body established at the $9^{\text {th }}$ SAARC Summit in 1997, proposed the formation of the South Asian Economic Union by 2020 (see SAARC, 1999). This was conceptualized as an achievement of regional economic cooperation and integration in successive stages - the establishment of SAFTA, followed by the formation of the South Asian Customs Union by 2015 alone, and initiation of the process to reach the proposed South Asian Economic Union 4-5 years earlier than planned.

${ }^{2}$ Sri Lanka's bilateral economic integration is expected to move beyond merchandise trade through its proposed comprehensive economic partnership agreement with India in 2003 and another with Pakistan in 2008. However, these agreements, the implementation of which was delayed, envisaged extending bilateral economic integration under all four modes of trade in services.
} 
related structural changes in trade patterns that might be identified as an outcome of the FTAs. The analysis shows that Sri Lanka's bilateral trade performance is peculiar-in cases where trade performance is better, it cannot all be attributed to the effectiveness of the FTAs alone; in cases where trade performance is worse, it cannot all be attributed to the ineffectiveness of the FTAs alone. The article confirms that the role of an FTA in terms of trade expansion is limited and should not be considered the "best" option.

The rest of the article is organized as follows: Section 2 outlines Sri Lanka's bilateral and regional agreements, highlighting how the former have made the latter ineffective. Section 3 presents an analysis of Sri Lanka's bilateral trade with India and Pakistan, identifying the extent of the influence of bilateral FTAs on trade performance. Factors beyond the FTAs that need to be taken into account in analyzing bilateral trade performance are briefed in Section 4 . With a summary of the findings, a series of conclusions is drawn in Section 5.

\section{Sri Lanka's Regional and Bilateral Trade Agreements}

The agreement on SAPTA came into effect in 1995, that is, after 10 years of the establishment of SAARC in 1985. Under SAPTA, SAARC member countries envisaged promoting and sustaining regional trade and economic cooperation through the exchange of trade concessions. Although regional trade was expected to move forward under SAPTA through a reciprocal stage-by-stage approach focusing on the existing trade barriers, its progress was far below expectations, as acknowledged by SAARC (1999).

Perhaps it was not SAPTA but the unilateral trade liberalization process in the SAARC countries that provided the impetus for regional trade expansion. In between the formation of SAARC and the establishment of SAPTA, India and other countries in the SAARC region embarked on their unilateral policy reform process for trade liberalization. While Sri Lanka's economy had been liberalized since 1977, other South Asian countries, such as India, Pakistan, Bangladesh, and Nepal commenced trade liberalization in the early 1990s. Trade within the region increased from 2.4 percent in 1990 to 4.5 percent in 2000 and thereafter to a little over 5 percent in 2009 (FICCI, 2011, p. 5). Compared to this, regional trade accounted for 12 percent in East Asia and the Pacific, 19 percent in Latin America and the Caribbean, and 20 percent in Europe and Central Asia in 2009 (FICCI, 2011, p. 6). Trade liberalization in individual countries 
was instrumental in expanding regional trade and investment as well as in establishing subsequent multilateral and bilateral agreements.

After considerable delay, the agreement on SAFTA came into effect in 2005-superseding SAPTA - with the objective of promoting trade and economic cooperation among "contracting states" by eliminating trade barriers and facilitating cross-border trade. Member countries also agreed on the need to ensure equitable benefits of free trade among contracting states in order to create an effective mechanism for the implementation of the agreement, and to establish a framework for the deeper integration of the contracting states beyond the premises of SAFTA.

Within the first two years, under SAFTA India, Pakistan, and Sri Lanka (non-least developed contracting states or NLDCs) agreed to reduce tariff rates to 20 percent, and other SAARC countries (least developed contracting states or LDCs) to 30 percent (Table 1). India and Pakistan were expected to further reduce their tariff rates in the range of $0-5$ percent within the next five years, Sri Lanka within six years, and the LDCs within eight years. Trading partners were to be allowed to agree on the tariff ceiling of goods on the "sensitive list," which was expected to be revised and reduced every four years. The agreement also envisaged the elimination of quantitative restrictions (QRs) on trade and a review of paratariffs and nontariff barriers (NTBs) by the contracting states. Apart from the above, a series of additional measures was introduced for trade facilitation. According to the SAFTA Rules of Origin, Sri Lanka as a "small" non-LDC country should satisfy the minimum domestic value addition (DVA) of 35 percent of the f.o.b. value. If part of the inputs originated from a contracting country, the aggregate input content should be at least 50 percent of the f.o.b. value as aggregate value addition if part of the inputs originated from other contracting countries.

During the 10-year period between the establishment of SAPTA (1995) and SAFTA (2005), however, Sri Lanka had progressed far ahead in terms of its regional economic integration, leaving little space to be covered by SAFTA. This had been achieved through the unilateral trade liberalization in the region and the bilateral FTAs into which it had entered with India and Pakistan. The scope left for SAFTA to cover was Sri Lanka's economic integration with the other SAARC countries. SAFTA did not, therefore, appear to be particularly effective in strengthening Sri Lanka's economic integration with these countries. Sri Lanka had already established closer ties with the Maldives in terms of trade and investment due to factors beyond the regional agreements in question. There was little 
economic integration between Sri Lanka and Nepal and Bangladesh, and an insignificant degree with Bhutan and Afghanistan. In spite of SAFTA, Sri Lanka's weak integration with these countries remained so without any major breakthrough subsequent to the agreement.

Table 1: Summary of the agreement on SAFTA (2005)

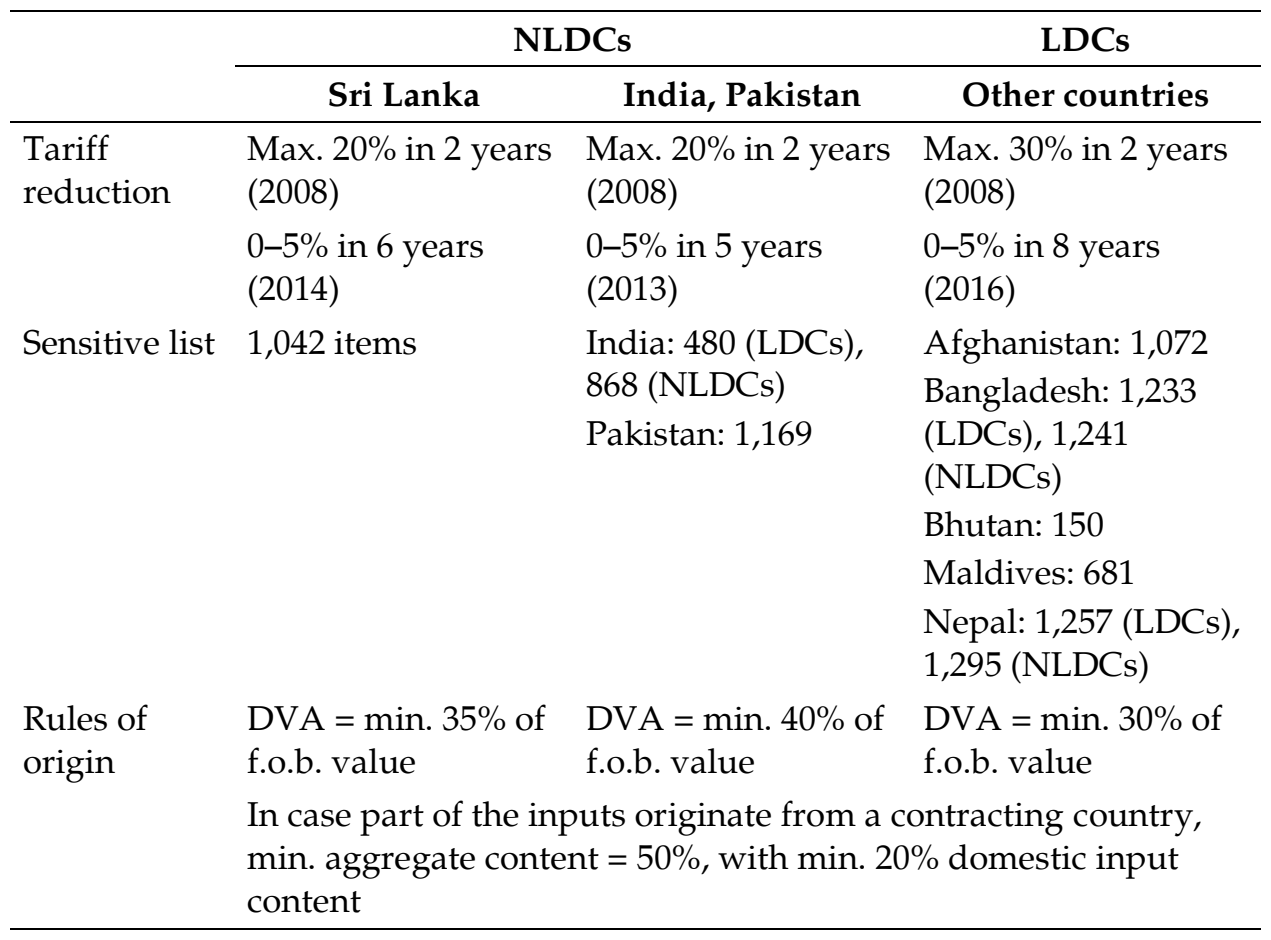

Source: SAARC Secretariat. Retrieved from www.saarc-sec.org

Sri Lanka's FTAs with India (ILFTA) and Pakistan (PLFTA) surpass the regional trade agreement (SAFTA) in terms of the depth of free trade, its time span of progress, and rules of origin (Table 2). This means that the country's bilateral trade with both India and Pakistan has performed under the bilateral agreements that made SAFTA ineffective. As we have already seen, Sri Lanka's bilateral trade with the other SAARC countries also made only marginal progress during the second half of the 2000s when SAFTA was effective (Abeyratne, 2012). The country's regional trade performance can, therefore, be explained better in the context of its bilateral trade agreements than its regional agreements.

The ILFTA was operational within 15 months of signing the agreement in December 1998, while the PLFTA came into force within three years of signing the agreement in July 2002, implying that bilateral 
agreements are more time-effective than regional or multilateral agreements. At the point of implementation, both trading partners had agreed on achieving zero tariffs for a range of tradable products and on the time duration for phasing out tariffs for the balance of items. In both cases, the agreements granted more "favorable" conditions and longer gestation periods for Sri Lanka than for India or Pakistan. Sri Lanka has also been entitled to a longer sensitive list than either India or Pakistan. In effect, whether or not these conditions actually remained "favorable" is an issue that has not been addressed. Sri Lanka's requirements-retaining "higher" tariffs, offering "shorter" lists of concessions, and receiving "longer" gestation periods-that are seen as "favorable" conditions could have actually led it to miss an opportunity to achieve lower production and consumption costs early.

Table 2: Summary of Sri Lanka's bilateral FTAs

\begin{tabular}{lll}
\hline \multicolumn{1}{c}{ Tariff reduction } & \multicolumn{1}{c}{ ILFTA (2000) } & \multicolumn{1}{c}{ PLFTA (2005) } \\
\hline (a) Immediate zero tariffs & India: 1,351 items & Pakistan: 206 items \\
& Sri Lanka: 319 items & Sri Lanka: 102 items \\
$\begin{array}{l}\text { (b) Tariff phasing-out } \\
\text { period }\end{array}$ & $\begin{array}{l}\text { 3 years for India (2003) } \\
\text { 8 years for Sri Lanka }\end{array}$ & $\begin{array}{l}\text { 3 years for Pakistan } \\
\text { (2008) }\end{array}$ \\
& & 5 years for Sri Lanka \\
Sensitive list & India: 431 & Pakistan: 540 \\
& Sri Lanka: 1220 & Sri Lanka: 697 \\
Rules of origin & DVA is 35\% of f.o.b. value \\
& In case part of the inputs originate from a \\
& contracting country, min. aggregate content $=35 \%$, \\
& with min. 25\% domestic input content \\
\hline
\end{tabular}

Source: Department of Commerce, Government of Sri Lanka. Retrieved from www.doc.gov.lk

As usual, the bilateral FTAs and SAFTA agreement were both characterized by "rules of origin" to safeguard the benefits of the agreements solely for their member countries, creating a market for production with greater value addition. On Sri Lanka's part, both the bilateral FTAs and SAFTA agreement do make a distinction for minimum DVA, which is 35 percent of the f.o.b. value of the export product. On the part of India and Pakistan, while domestic, the SAFTA requirement for DVA is 40 percent, which is greater than 35 percent under the bilateral FTAs. 
Both FTAs are fully effective now that Sri Lanka has completed the time periods for tariff liberalization under the ILFTA in 2008 and under the PLFTA in 2010. India completed tariff liberalization in 2003 and Pakistan in 2008, allowing Sri Lanka a longer adjustment period. Given this requirement under the bilateral FTAs, Sri Lanka and its trading partners have already moved beyond SAFTA's requirements to slash tariffs to $0-5$ percent by 2014 for Sri Lanka and by 2013 for India and Pakistan. Although it was reasonable to anticipate greater trade performance toward the end of the decade with the completion of the tariff liberalization process, Sri Lanka's bilateral trade with India and Pakistan has not reflected a significant change. It is, however, worth noting that the decade's last few years were marked by the adverse effects of external shocks, such as the US financial crisis and EU sovereign debt crisis, both of which affected trade performance in the SAARC region.

\section{Sri Lanka's Bilateral Trade with India and Pakistan}

Generally, an analysis of Sri Lanka's bilateral trade with India and Pakistan should acknowledge, apart from the bilateral agreements, the role played by the unilateral liberalization process and multilateral agreements for preferential and free trade in both bilateral and regional trade expansion. However slowly, Sri Lanka's trade with South Asian countries has grown in the past. As of 2011, exports to and imports from the South Asian countries account for 7 and 23 percent of the respective totals (Central Bank of Sri Lanka, 2011). The particular pattern of Sri Lanka's regional trade expansion has also led to certain questions in both policy and academic circles (see Abeyratne, 2012; Ahmed et al., 2010; Behera \& Mukherji, 2011; Weerakoon, 2009). While the South Asian region has become important as a source market for Sri Lanka's imports but not as a destination market for its exports, an overwhelming bulk of regional trade accounts for trade with India alone. Apart from that, Sri Lanka has significant bilateral trade relations with Pakistan, the Maldives, and Bangladesh. Its trade with Nepal is insignificant; with Bhutan, trivial and sporadic, and with Afghanistan, nonexistent.

\subsection{Bilateral Trade Performance}

Sri Lanka's regional trade is dominated by its bilateral trade with India, while in recent years the latter has remained among Sri Lanka's top five export destination markets. In fact, India has continued to improve its position as the single most important trading partner of all other countries in the region. During the first half of the 1990s, Sri Lanka's exports to India 
were lower than its exports to Pakistan. Exports to India, which accounted for about 30 percent of total exports to countries in the region in 2000, rose sharply in the first half of the 2000s, exceeding 80 percent after the implementation of the ILFTA in 2000 (Table 3). The share of exports to Pakistan-accounting for over 40 percent of total exports to SAARCcontinued to decline, reaching 6.7 percent of total exports to SAARC in 2005. After the implementation of the PLFTA in 2005, however, exports to Pakistan recorded a slight improvement.

India is Sri Lanka's largest source market for imports, followed by Singapore and China in second and third position, respectively. Imports from India have continued to rise since the mid-1990s and, on average, account for about 90 percent of Sri Lanka's total imports from the SAARC region. This means that the other member countries account for only about 10 percent of Sri Lanka's imports from the region. Two decades ago, however, Pakistan-then, an important source market for Sri Lanka's imports-contributed to over 25 percent of Sri Lanka's total imports from the region. The share of imports from Pakistan recorded a sharp decline in the first half of the 1990s and dropped to around 10 percent in 2001 and 2002. It declined further in the decade's subsequent years, reaching 5 percent by 2008 , but later improved.

Table 3: Sri Lanka's exports to and imports from SAARC

\begin{tabular}{crccccc}
\hline & \multicolumn{3}{c}{ Exports to SAARC } & \multicolumn{3}{c}{ Imports from SAARC } \\
\cline { 2 - 7 } Year & USD mn & India (\%) & Pakistan (\%) & USD mn & India (\%) & Pakistan (\%) \\
\hline 1990 & 71 & 29.1 & 45.8 & 183 & 64.1 & 27.6 \\
1995 & 97 & 31.3 & 42.5 & 516 & 86.1 & 9.6 \\
2000 & 180 & 30.6 & 15.7 & 669 & 84.8 & 10.2 \\
2001 & 151 & 45.6 & 15.8 & 683 & 84.4 & 10.4 \\
2002 & 254 & 66.5 & 11.2 & 925 & 89.2 & 7.0 \\
2003 & 350 & 70.0 & 10.5 & 1,173 & 91.5 & 6.1 \\
2004 & 507 & 77.3 & 7.8 & 1,575 & 91.4 & 6.9 \\
2005 & 653 & 86.7 & 6.7 & 1,981 & 92.6 & 5.8 \\
2006 & 600 & 81.5 & 9.7 & 2,351 & 92.4 & 6.3 \\
2007 & 646 & 79.7 & 8.5 & 2,815 & 92.7 & 6.3 \\
2008 & 561 & 74.5 & 12.7 & 3,667 & 94.0 & 5.2 \\
2009 & 441 & 73.0 & 12.5 & 2,055 & 88.6 & 9.6 \\
2010 & 601 & 77.5 & 10.0 & 2,877 & 89.3 & 9.8 \\
\hline
\end{tabular}

Source: Central Bank of Sri Lanka (Annual Report for various years). 
Sri Lanka's trade expansion in the SAARC region and with India in particular has been accompanied by a growing trade deficit. The evidence indicates that it has never had a trade surplus during its 35-year liberalized trade regime, while the overall trade deficit has increased sharply in the past decade (Figure 1). The movement of the overall trade deficit resembles the country's growing regional trade deficit with the SAARC countries in general and with India in particular. However, Sri Lanka's trade deficit with SAARC has remained cushioned by its trade surplus with the US and EU-its two largest export destinations, which together account for over half the country's total exports.

Sri Lanka also has a trade deficit with Pakistan-the country's second-largest trading partner in the SAARC region. Although this trade deficit is not as large as the trade deficit with India, it appears to have been rising sharply after 2005 (Figure 2). This also coincides with the implementation of the PLFTA, resembling the growing trade deficit with India after the implementation of the ILFTA. This episode does not, however, lead to an early conclusion against Sri Lanka's two bilateral FTAs in the SAARC region. It is possible that growing imports from both India and Pakistan are a result of trade diversion, and may have a positive impact on the country's trade with the rest of the world and on its welfare performance. Moreover, it is too early to suggest that the increase in its bilateral trade deficits with India and Pakistan are an exclusive outcome of the FTAs - an issue with which we deal in the following section.

Figure 1: Sri Lanka's trade balance, 1990-2010

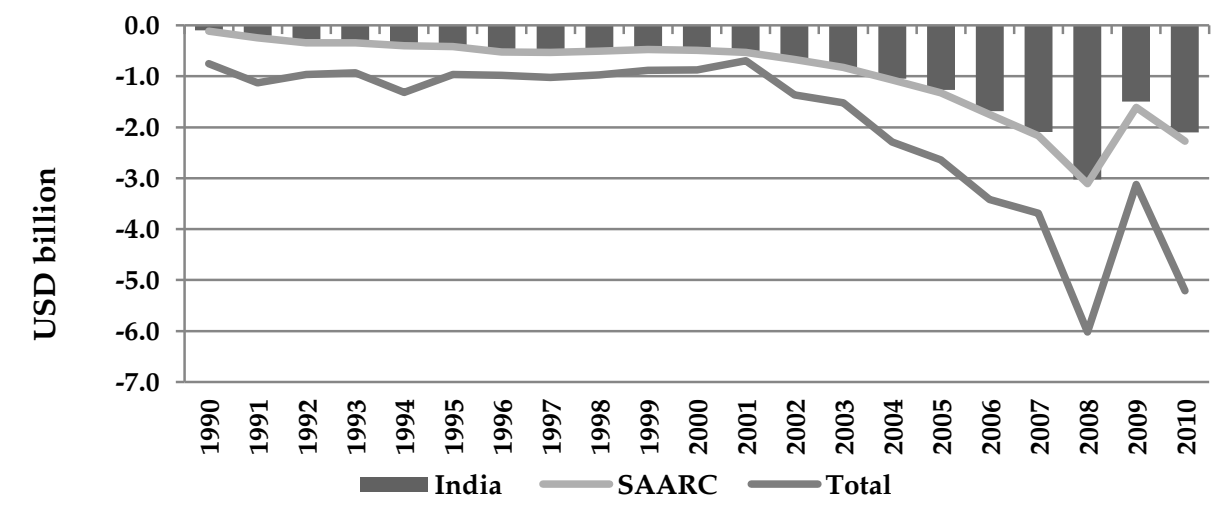

Source: Central Bank of Sri Lanka (Annual Report for various years). 
Figure 2: Sri Lanka's Trade Deficit with Pakistan, 1995-2010

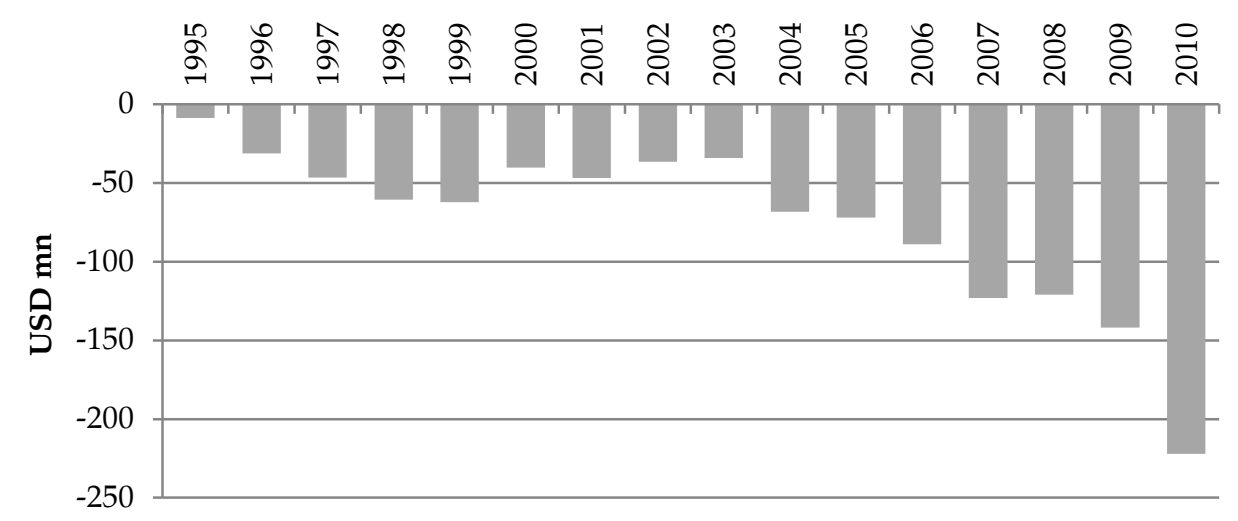

Source: Central Bank of Sri Lanka (Annual Report for various years).

\subsection{Trade Performance Within and Beyond the FTAs}

Sri Lanka's two bilateral FTAs, the ILFTA (2000) and PLFTA (2005) have brought a significant share of the products that were exported to and imported from India and Pakistan under free trade through a gradual process of phasing out tariff barriers. As the Sri Lankan Customs Department (n.d.) reports, 91.8 percent of total imports from India $(6,522$ products) and 85.7 percent of total exports to India (1,765 products) were covered by the ILFTA (Table 4). Similarly, 80.8 percent of imports from Pakistan (1,492 products) as well as the same percentage of exports to Pakistan (470 products) were covered by the PLFTA.

Table 4: Exports and imports under FTAs with India and Pakistan, 2010

\begin{tabular}{llcrcr}
\hline & & \multicolumn{2}{c}{ Products } & \multicolumn{2}{c}{ Value } \\
\cline { 3 - 6 } FTA & Imports/exports & No. of products a & Percent & USD million & Percent \\
\hline ILFTA & FTA imports & 6,522 & 91.8 & 1,418 & 56.3 \\
& Total imports & 7,107 & 100.0 & 2,517 & 100.0 \\
& FTA exports & 1,765 & 85.7 & 423 & 88.2 \\
& Total exports & 2,059 & 100.0 & 480 & 100.0 \\
PLFTA & FTA imports & 1,492 & 80.8 & 193 & 67.2 \\
& Total imports & 1,847 & 100.0 & 287 & 100.0 \\
& FTA exports & 470 & 80.8 & 50 & 80.7 \\
& Total exports & 582 & 100.0 & 62 & 100.0 \\
\hline
\end{tabular}

a = HS 6-8-digit classifications, as reported in the data source.

Source: Sri Lanka Customs Department. 
The value of imports covered by the FTAs is, however, not as great as the volume of products they cover. The FTAs cover only 56.3 percent of imports from India and 67.2 percent of imports from Pakistan, indicating that non-FTA imports also remain significant. In fact, under the ILFTA, Sri Lanka's negative list covers 1,220 products (at HS Code 6-digit level), affecting its imports from India, compared to the latter's negative list of 431 products, affecting Sri Lanka's exports to India. In contrast, under the PLFTA, Sri Lanka's negative list covered 697 products while Pakistan's negative list covered 540 products (at HS Code 6-digit level). The value of exports to both India and Pakistan, however, closely resemble the share of export products covered by the respective FTAs.

Sri Lanka's bilateral trade with India and Pakistan before and after entering into their respective FTAs, as well as within and outside those FTAs, reveals some peculiar characteristics of the country's regional trade expansion (Table 5). After the ILFTA's implementation in 2000, trade expansion during the first half of the decade (2000-05) was remarkableon average, per annum exports grew by over 300 percent and imports by nearly 200 percent. During the second half of the decade (2005-10), exports contracted by 2.7 percent while imports grew by only 12.8 percent, presumably due both to internal policy changes and external shocks. The expansion of FTA exports was greater than non-FTA exports in the first half of the decade, but not in the second half. Although Sri Lanka's long negative list affected imports from India, the expansion of non-FTA imports was greater than that of FTA imports throughout the decade. 
Table 5: Exports from and imports to India and Pakistan: Average annual rate of growth, 1995-2010

\begin{tabular}{lccc}
\hline Trade & $\mathbf{1 9 9 5 - 2 0 0 0}$ & $\mathbf{2 0 0 0 - 0 5}$ & $\mathbf{2 0 0 5 - 1 0}$ \\
\hline Trade with India & Before FTA & After FTA & After FTA \\
FTA exports & 14.0 & 308.8 & -4.7 \\
Non-FTA exports & 0.6 & 198.8 & 33.4 \\
Total exports & 12.0 & 301.6 & -2.7 \\
FTA imports & 5.1 & 192.3 & 12.7 \\
Non-FTA imports & 4.9 & 211.8 & 13.0 \\
Total imports & 5.0 & 199.9 & 12.8 \\
\hline Trade with Pakistan & Before FTA & Before FTA & After FTA \\
FTA exports & -7.4 & 12.8 & 8.8 \\
Non-FTA exports & -6.9 & -1.0 & 4.1 \\
Total exports & -7.3 & 8.6 & 7.7 \\
FTA imports & 2.9 & 19.3 & 15.0 \\
Non-FTA imports & 13.3 & -9.0 & 39.5 \\
Total imports & 6.6 & 10.7 & 20.3 \\
\hline
\end{tabular}

Source: Sri Lanka Customs Department.

It is clear that the ILFTA was more important for export expansion than for import expansion. Abeyratne and Ranasinghe (2004) and Samarajiva and Herath (2009) confirm that Sri Lanka has been diverting its import trade from the rest of the world toward India in the last two decades due to cost differences. Moreover, the policy outcome of post-1990 liberalization reforms in India has been instrumental on its part to meeting this demand. Since Sri Lanka also imports a bulk of intermediate goods and raw materials from India, the particular pattern of production specialization in Sri Lanka could be an underlying factor in the changes in import growth. Compared to the import growth that picked up in the early 2000 's and continued to remain high throughout the decade (except in 2009), export growth steadily declined after initially increasing in the early 2000's and remained negative for some years after 2005.

Although it is too early to make a fair assessment, Sri Lanka's bilateral trade with Pakistan has grown rapidly during 2005-10 after the implementation of the PLFTA in 2005, but mostly in areas outside the FTA. The average annual rate of export growth declined to 7.7 percent during 2005-10 from 8.6 percent during 2000-05, with an increase in non-FTA export growth and a decrease in FTA export growth. Between the same 
periods, the average annual rate of import growth nearly doubled from 10.7 to 20.3 percent, with an increase in non-FTA import growth and a decrease in FTA import growth. The Sri Lankan experience with the PLFTA also suggests that there was a revival of Sri Lanka's bilateral trade with Pakistan, but factors beyond the PLFTA appear to have had a greater impact on this revival of bilateral trade.

\subsection{Changes in Export and Import Structures}

Trade expansion under bilateral FTAs has been accompanied by substantial changes in export and import composition. Prior to the ILFTA, Sri Lankan exports to India were dominated by primary goods, paper waste and scrap, and ferrous waste and scrap (Table 6). Subsequent to its implementation, there has been an increase in the share of manufactured exports to India. Some of these manufactured exports include new products entering the Indian market, such as animal feed, fiberboard, furniture, and ships and boats. Some of the fast growing exports, particularly copper and copper products, and fats and oils (vanaspathy in particular) grew in response to the tariff concessions under the ILFTA, but declined after the trade restrictions were reversed. Among non-FTA exports, natural rubber accounted for over 60 percent, and apparel and clothing for nearly 25 percent of total non-FTA exports to India in 2010. In 2000, plastic and rubber articles, and synthetic filament yarn dominated non-FTA exports, accounting for about three fourths of total non-FTA exports to India.

Sri Lanka's import mix from India has always been far more diverse than its export mix. Pharmaceutical products, cotton yarn, woven cotton fabrics, and iron and steel dominated FTA imports in 2000 (Table 7). Even after the implementation of the ILFTA, these imports remained important although their share of total imports appears to have declined. One notable increase in the share of imports has been that of motorcycles, parts, and accessories, which increased from 2 to 10.5 percent of total FTA imports. Among non-FTA imports, the share of petroleum and passenger vehicles has increased significantly, together accounting for more than half of total non-FTA imports by 2010. While the oil price hike as well as the Indian oil industry's entry into the Sri Lankan petroleum sector may have contributed to the increase in share of petroleum imports, the rising demand for cheaper Indian motor vehicles would have caused the increase in share of vehicle imports. In fact, the Indian motor vehicle industry also improved its international competitiveness only after India initiated policy reforms so that the industry was able to promote exports competitively. 
Table 6: Main FTA and non-FTA exports to India, 1995-2010 (selected years)

\begin{tabular}{|c|c|c|c|c|c|}
\hline Code & Export & 1995 & 2000 & 2005 & 2010 \\
\hline \multicolumn{6}{|c|}{ Main FTA exports (as percentage of total FTA exports) } \\
\hline 0508 & Coral products & 0.0 & 1.4 & 0.1 & 0.3 \\
\hline 08 & Fruits and nuts & 7.4 & 4.1 & 0.2 & 0.9 \\
\hline 0902 & Tea & 1.4 & 7.5 & 0.2 & 0.3 \\
\hline 0904-0910 & Spices & 7.0 & 29.1 & 5.9 & 16.7 \\
\hline $151-152$ & Fats and oils & 12.3 & 4.8 & 26.2 & 0.0 \\
\hline 180 & Cocoa and cocoa preparations & 0.0 & 0.2 & 0.0 & 4.4 \\
\hline 2309 & Animal feed & 0.0 & 0.0 & 0.0 & 10.5 \\
\hline 4011-4015 & Rubber products & 0.7 & 1.1 & 1.1 & 4.8 \\
\hline 4411 & Fiberboard of wood and other & 0.0 & 0.0 & 1.9 & 2.6 \\
\hline 4707 & Paper waste and scrap & 5.6 & 7.6 & 2.0 & 5.0 \\
\hline $5804-5807$ & Woven fabrics and textiles & 0.1 & 0.4 & 0.4 & 1.7 \\
\hline 7204 & Ferrous waste and scrap & 25.0 & 10.4 & 1.9 & 0.1 \\
\hline $7402-7413$ & Copper and copper products & 4.6 & 2.2 & 28.4 & 5.9 \\
\hline 7801-7802 & Lead, unwrought, waste and scrap & 0.0 & 0.1 & 0.4 & 2.2 \\
\hline 8418 & Machinery & 0.2 & 0.0 & 0.2 & 4.7 \\
\hline 8544 & Insulated electric conductors & 0.2 & 0.4 & 3.6 & 8.9 \\
\hline 89 & Ships and boats & 0.0 & 0.0 & 0.0 & 4.5 \\
\hline 9403 & Furniture & 0.0 & 0.3 & 1.0 & 1.7 \\
\hline \multirow[t]{2}{*}{ Total } & (Percentage of total FTA exports) & 64.5 & 69.5 & 73.2 & 75.6 \\
\hline & (USD million) & 16.0 & 33.0 & 393.0 & 320.0 \\
\hline All FTA exp & orts (USD million) & 24.0 & 47.0 & 537.0 & 423.0 \\
\hline \multicolumn{6}{|c|}{ Main non-FTA exports (as percentage of total non-FTA exports) } \\
\hline 3926 & Plastic and rubber articles & 1.1 & 45.8 & 47.3 & 2.6 \\
\hline $400121-129$ & Natural rubber & 92.7 & 8.4 & 16.8 & 60.3 \\
\hline 48 & Paper and paperboard & 1.6 & 8.9 & 14.9 & 4.5 \\
\hline 5402 & Synthetic filament yarn & 0.0 & 29.7 & 0.6 & 1.9 \\
\hline 61-62 & Apparel and clothing & 0.1 & 1.6 & 3.7 & 24.9 \\
\hline \multirow[t]{2}{*}{ Total } & (Percentage of total non-FTA exports) & 95.5 & 94.3 & 83.2 & 94.2 \\
\hline & (USD million) & 5.0 & 5.0 & 11.0 & 53.0 \\
\hline \multicolumn{2}{|c|}{ All non-FTA exports (USD million) } & 6.0 & 6.0 & 13.0 & 57.0 \\
\hline
\end{tabular}

Source: Sri Lanka Customs Department. 
Table 7: Main FTA and non-FTA imports from India, 1995-2010 (selected years)

\begin{tabular}{|c|c|c|c|c|c|}
\hline Code & Import & 1995 & 2000 & 2005 & 2010 \\
\hline \multicolumn{6}{|c|}{ Main FTA imports (as percentage of total FTA imports) } \\
\hline 2304-2308 & Oil cakes and solid residues & 2.9 & 3.8 & 3.5 & 2.3 \\
\hline 2523 & Portland cement & 12.6 & 3.7 & 3.7 & 5.0 \\
\hline 2803 & Carbon & 1.1 & 1.5 & 2.3 & 1.7 \\
\hline 30 & Pharmaceutical products & 7.0 & 8.9 & 7.6 & 7.5 \\
\hline 3303-3307 & Cosmetic and toilet preparations & 0.2 & 0.8 & 0.6 & 0.7 \\
\hline 3401-3402 & Soap and washing preparations & 0.2 & 0.2 & 0.4 & 0.7 \\
\hline 381900 & Hydraulic brake and transmission fluids & 1.1 & 1.2 & 0.9 & 0.9 \\
\hline 390 & Plastics & 2.8 & 1.8 & 3.0 & 2.4 \\
\hline $5205-5207$ & Cotton yarn & 5.6 & 8.1 & 3.9 & 4.7 \\
\hline $5208-5212$ & Woven fabrics of cotton & 12.5 & 12.2 & 6.7 & 7.4 \\
\hline $5512-5516$ & Woven fabrics of synthetic and artificial fibers & 1.2 & 3.1 & 1.5 & 2.0 \\
\hline $6002-6006$ & Knitted or crocheted fabrics & 1.4 & 0.8 & 1.7 & 4.8 \\
\hline 72 & Iron and steel & 9.7 & 7.0 & 7.6 & 6.0 \\
\hline 73 & Iron and steel products & 3.6 & 3.3 & 2.8 & 3.0 \\
\hline 74 & Copper and copper products & 0.4 & 0.3 & 4.5 & 3.7 \\
\hline 8418 & Refrigerators, freezers, and equipment & 0.1 & 0.5 & 0.7 & 0.8 \\
\hline $8501-8503$ & Electric motors, generators, and parts & 0.3 & 0.4 & 0.4 & 2.3 \\
\hline $870422-423$ & Motor vehicles for goods transport & 2.6 & 1.1 & 5.3 & 4.6 \\
\hline $8711 \& 8714$ & Motorcycles, parts, and accessories & 2.1 & 2.0 & 10.9 & 10.5 \\
\hline \multirow[t]{2}{*}{ Total } & (Percentage of total FTA imports) & 67.6 & 60.8 & 68.0 & 71.0 \\
\hline & (USD million) & 193.0 & 222.0 & 530.0 & $1,006.0$ \\
\hline \multicolumn{2}{|c|}{ All FTA imports (USD million) } & 286.0 & 365.0 & 780.0 & $1,418.0$ \\
\hline \multicolumn{6}{|c|}{ Main non-FTA imports (as percentage of total non-FTA imports) } \\
\hline 070110 & Potatoes & 1.8 & 2.9 & 0.9 & 1.4 \\
\hline 070310 & Onions and shallots & 0.0 & 0.0 & 0.0 & 5.1 \\
\hline 0713 & Dried leguminous vegetables & 3.4 & 14.3 & 4.1 & 1.6 \\
\hline 0902 & Tea & 0.2 & 0.9 & 0.7 & 1.2 \\
\hline 0904-0910 & Spices & 7.4 & 9.2 & 2.9 & 5.2 \\
\hline 170111-199 & Sugar & 14.2 & 3.6 & 0.4 & 3.3 \\
\hline 190190 & Malt extracts & 1.8 & 0.3 & 0.6 & 1.0 \\
\hline $2710-2714$ & Petroleum oils and other products & 0.0 & 0.1 & 32.7 & 32.1 \\
\hline $4011-4013$ & Rubber tyres and tubes & 2.4 & 1.7 & 1.1 & 1.3 \\
\hline 4802 & Uncoated paper and paperboard & 0.0 & 0.0 & 4.4 & 3.5 \\
\hline 4810 & Paper and paperboard & 0.0 & 0.1 & 2.1 & 2.4 \\
\hline $8544 \& 8546$ & Insulated electric conductors and insulators & 0.3 & 1.8 & 0.9 & 1.0 \\
\hline $8702-8703$ & Passenger vehicles & 10.7 & 17.7 & 16.7 & 21.2 \\
\hline 8704 & Motor vehicles for transport of goods & 3.1 & 0.3 & 1.9 & 3.6 \\
\hline \multirow[t]{2}{*}{ Total } & (Percentage of total non-FTA imports) & 45.4 & 53.0 & 69.4 & 83.8 \\
\hline & (USD million) & 72.0 & 107.0 & 415.0 & 921.0 \\
\hline \multicolumn{2}{|c|}{ All non-FTA imports (USD million) } & 159.0 & 203.0 & 597.0 & $1,099.0$ \\
\hline
\end{tabular}

Source: Sri Lanka Customs Department. 
Exports to Pakistan have concentrated on a few commodities, while more than half of FTA exports in 2010 consisted of natural rubber alone (Table 8). In addition, coconut, spices, and rubber products also form part of Sri Lanka's main FTA exports, the share of which has increased after the implementation of the PLFTA.

Table 8: Main FTA and non-FTA exports to Pakistan, 1995-2010 (selected years)

\begin{tabular}{|c|c|c|c|c|c|}
\hline Code & Export & 1995 & 2000 & 2005 & 2010 \\
\hline \multicolumn{6}{|c|}{ Main FTA exports (as percentage of total FTA exports) } \\
\hline 071340 & Lentils & 0.0 & 0.0 & 0.0 & 4.2 \\
\hline 080110-19 & Coconut & 12.5 & 18.7 & 8.0 & 12.4 \\
\hline 0904-0910 & Spices & 2.2 & 5.7 & 2.4 & 7.0 \\
\hline 120300 & Copra & 17.8 & 39.0 & 38.8 & 1.0 \\
\hline 230 & Bran, sharps, and other residues & 0.3 & 1.6 & 0.3 & 4.1 \\
\hline 4001 & Natural rubber & 46.2 & 19.2 & 28.2 & 51.1 \\
\hline 400821 & Vulcanized rubber products & 0.0 & 0.0 & 0.1 & 2.6 \\
\hline $4002-4015$ & Rubber products & 0.4 & 0.3 & 0.6 & 5.0 \\
\hline 4411 & Fiberboard & 0.0 & 0.0 & 7.5 & 2.6 \\
\hline 550810 & Sewing thread & 0.0 & 0.0 & 0.8 & 2.6 \\
\hline \multirow[t]{2}{*}{ Total } & (Percentage of total FTA exports) & 79.5 & 84.6 & 86.6 & 92.8 \\
\hline & (USD million) & 21.0 & 15.0 & 28.0 & 46.0 \\
\hline \multicolumn{2}{|c|}{ All FTA exports (USD million) } & 26.0 & 18.0 & 33.0 & 50.0 \\
\hline \multicolumn{6}{|c|}{ Main non-FTA exports (as percentage of total non-FTA exports) } \\
\hline 0902 & Tea & 75.5 & 73.2 & 62.8 & 26.4 \\
\hline 140490 & Beedi and betel leaves & 7.9 & 15.2 & 25.4 & 44.0 \\
\hline 140490 & Coconut ekels & 0.0 & 0.0 & 0.0 & 5.3 \\
\hline $1511-1513$ & Coconut and palm oil & 3.2 & 8.2 & 3.3 & 15.8 \\
\hline 760720 & Aluminum foil & 0.0 & 0.0 & 0.0 & 2.3 \\
\hline \multirow[t]{2}{*}{ Total } & (Percentage of total non-FTA exports) & 86.6 & 96.7 & 91.5 & 93.8 \\
\hline & (USD million) & 13.0 & 10.0 & 9.0 & 11.0 \\
\hline \multicolumn{2}{|c|}{ All non-FTA exports (USD million) } & 15.0 & 10.0 & 10.0 & 12.0 \\
\hline
\end{tabular}

Source: Sri Lanka Customs Department.

Non-FTA exports to Pakistan have been concentrated around tea, beedi and betel leaves, and coconut, which together accounted for over 86 percent of total non-FTA exports in 2010. Under the PLFTA, however, the importance of tea has declined, while the share of the other two exports has risen.

Yarn and fabrics for Sri Lanka's textile and apparel industry have dominated FTA imports from Pakistan, accounting for about 72 percent 
of total FTA imports in 2005 (Table 9). The importance of this intermediate group of goods has remained high even after the implementation of the PLFTA, even though its share fell, mainly due to the entry of cement as a newly imported commodity from Pakistan. In the non-FTA category, the import mix continued to be dominated by dried fish, potatoes, onions, and rice.

Table 9: Main FTA and non-FTA imports from Pakistan, 1995-2010 (selected years)

\begin{tabular}{|c|c|c|c|c|c|}
\hline Code & Import & 1995 & 2000 & 2005 & 2010 \\
\hline \multicolumn{6}{|c|}{ Main FTA imports (as percentage of total FTA imports) } \\
\hline 0909 & Seeds and spices & 0.2 & 2.9 & 1.7 & 2.7 \\
\hline 2523 & Cement & 0.0 & 0.0 & 0.0 & 15.5 \\
\hline 3002-3004 & Pharmaceutical products & 7.5 & 8.7 & 4.9 & 4.3 \\
\hline $4101-4112$ & Leather & 6.7 & 2.6 & 0.5 & 1.5 \\
\hline $5201-5207$ & Cotton and cotton yarn & 23.4 & 16.4 & 7.3 & 2.9 \\
\hline $5208-5212$ & Woven fabrics of cotton & 34.3 & 27.6 & 58.8 & 44.5 \\
\hline $5512-5515$ & Woven fabrics of synthetic fibers & 7.5 & 4.1 & 2.8 & 3.2 \\
\hline $6001-6006$ & Knitted or crocheted fabrics & 4.7 & 3.8 & 2.5 & 8.2 \\
\hline 7304-7307 & Tubes, pipes, and fittings & 0.1 & 7.0 & 7.0 & 7.3 \\
\hline \multirow[t]{2}{*}{ Total } & (Percentage of total FTA imports) & 84.9 & 78.3 & 89.5 & 94.8 \\
\hline & (USD million) & 29.0 & 31.0 & 86.0 & 183.0 \\
\hline All FTA in & ports (USD million) & 34.0 & 40.0 & 96.0 & 193.0 \\
\hline \multicolumn{6}{|c|}{ Main non-FTA imports (as percentage of total non-FTA imports) } \\
\hline 0305 & Dried fish & 84.1 & 39.6 & 27.4 & 3.7 \\
\hline 0701 & Potatoes & 0.0 & 33.3 & 9.0 & 21.5 \\
\hline 0703 & Onions shallots & 1.7 & 12.5 & 9.3 & 9.5 \\
\hline 1006 & Rice & 8.0 & 6.4 & 26.7 & 56.8 \\
\hline 2207 & Alcohol and spirits & 0.0 & 0.0 & 0.0 & 1.6 \\
\hline 4805 & Paper and paperboard & 0.0 & 0.0 & 0.0 & 2.3 \\
\hline \multirow[t]{2}{*}{ Total } & (Percentage of total non-FTA imports) & 94.4 & 92.2 & 80.5 & 96.6 \\
\hline & (USD million) & 14.0 & 26.0 & 14.0 & 91.0 \\
\hline \multicolumn{2}{|c|}{ All non-FTA imports (USD million) } & 15.0 & 29.0 & 18.0 & 94.0 \\
\hline
\end{tabular}

Source: Sri Lanka Customs Department.

\section{Factors beyond the FTAs}

It is clear that Sri Lanka's two FTAs with India and Pakistan do not fully explain the country's bilateral trade performance. Both exports and imports have increased in general, but the expansion has been stronger with India than with Pakistan. Bilateral trade deficits have also increased more rapidly with India than with Pakistan. Sri Lankan exports to India 
have diversified, but not so in the case of Sri Lankan exports to Pakistan. The changes altering Sri Lanka's bilateral trade with India and Pakistan during the periods that fall under their respective FTAs, therefore, demand a discussion on factors beyond the FTAs.

\subsection{Overall Connectivity}

The proximity and large size of the market, together with stronger economic relations beyond merchandise trade are important in explaining Sri Lanka's growing trade ties with India with or without the ILFTA. In fact, merchandise trade did not exist in isolation from other forms of growing economic relations between the two countries. Sri Lanka has even stronger relations with India in the services trade, travel and tourism, and investment. India is a growing source market for demand for education and health services by Sri Lanka, while the latter supplies port and aviation services to the former. According to the aviation statistics of Sri Lanka, Indian destinations accounted for 34 percent of weekly flights while the only Pakistani destination, Karachi, accounted for only 2 percent of flights departing from Colombo International Airport in 2011. More than three fourths of container traffic in Colombo Port in 2010 consisted of transshipment cargo portions, but about 90 percent of the transshipment volume originated from India alone, implying that the very existence of Colombo Port rests largely on Indian transshipment activities (Ratnayake, 2011).

Tourism is an important area of the services trade in which Sri Lankan connectivity with India is stronger than that with Pakistan. India emerged as the leading country of tourist origin for Sri Lanka in 2002, ousting traditional Western countries such as the UK and Germany, and continued to be so throughout the 2000s. Compared to 125,000 tourist arrivals from India in 2010, there were only 9,000 Pakistani tourists (Sri Lanka, Tourism Development Authority, 2010). While India is the largest destination for outbound Sri Lankan tourists, their number is, interestingly, much larger than that of Indian tourists visiting Sri Lanka. Sri Lanka is currently India's sixth largest source market, and was third and fourth in the first half of the decade (India, Ministry of Tourism, 2011).

India has been among Sri Lanka's top five sources of foreign direct investment (FDI) in much of the recent past. It was elevated to first position in 2010, contributing 21.4 percent of Sri Lanka's total USD 516.3 million FDI inflow. According to Samarajiva and Herath (2009), Sri Lanka become an attractive destination for Indian FDI particularly after 2000, while about 
half of India's FDI in the SAARC region is located in Sri Lanka. In fact, Indian FDI in Sri Lanka increased in the early part of the decade due to the implementation of the ILFTA particularly to gain from the bilateral free trade between the two countries. Apart from this, the importance of potential Indian FDI inflows to Sri Lanka has been recognized on various occasions. For instance, Sri Lanka and India entered into the bilateral Investment Promotion and Protection Agreement in 1997, while Sri Lanka set up its Board of Investment's first overseas office in Bangalore in 2005.

Although among the other South Asian countries, Pakistan is also important as a source of FDI for Sri Lanka, its contribution remains at around 0.1 percent of the latter's total FDI inflows. There has, however, been an increase in FDI from Pakistan to Sri Lanka since the mid-2000s, indicating that the PLFTA has had a positive impact on FDI inflows.

\subsection{Contemporary Shocks and Policy Changes}

In terms of both internal and external shocks affecting domestic economies and their international relations, the second half of the decade (2005-10) did not appear to be normal. Sri Lanka's civil war escalated during 2007-09, followed by a massive program of rehabilitation and reconstruction. Global economic turmoil commenced with world oil and food price hikes, followed by the US financial crisis and the EU debt crisis, which affected the economies in South Asia as elsewhere. Against this backdrop, it was not unusual for trade to perform dismally under the justinitiated PLFTA. Bilateral trade between Sri Lanka and India, which had performed remarkably well during the first half of the decade, also came under pressure during the second half of the decade.

Policy changes, particularly during the Sri Lankan government's post-2005 regime, have also had a bearing on the country's trade performance. The new policy thrust favored domestic production and increased protectionism, which could be justified against both internal and external shocks-intensified war that required expanding government revenues and the global crises that justified increased protectionism and domestic production. This resulted in an increase in the share of domestic production in the output composition and a decline in trade volume as a percentage of GDP (Abeyratne, 2009). As Pursell (2011) argues, Sri Lanka has resorted to para-tariffs and new protectionist measures in the second half of the decade since the tariffs were falling under the WTO and FTA commitments. In a protective environment, the bilateral FTAs might not yield an optimal outcome since they could distort emerging trade patterns. 
In addition to the increased transaction costs of economic integration under the numerous FTAs, the conditions laid down could actually restrict trade performance. This is particularly applicable to a "small" country more so than to a "large" country-a point that has been well recognized by the FTAs as well. However, the question is whether the specific country provisions under the FTAs can actually deal with the issue effectively. An obvious example concerns the rules of origin that constrain trade specialization by internationalizing production processes. An important characteristic of trade expansion in the recent past is the increasing tendency to "slice up" the production process into parts, components, and assembly; it is no longer the "unit value" but the "volume" that has become important in international trade (Athukorala, 2011). Therefore, the strict conditions stipulated by the rules of origin can lead not only to inefficient production specialization that contravene the notion of comparative advantage, but also inhibit intraregional trade.

\section{Conclusion}

The preceding analysis has examined whether Sri Lanka's bilateral FTAs with India (ILFTA) in 2000 and with Pakistan (PLFTA) in 2005 have resulted in a difference to the country's normal trade patterns. Trade performance within the South Asian region is interesting because it represents a growth paradox. Trade within the region has not performed as well as its high economic growth might suggest, despite trade liberalization and initiatives for regional integration-SAPTA and SAFTA. Bilateral arrangements through the ILFTA and PLFTA have made regional arrangements redundant due to deeper tariff reforms, shorter periods of tariff phasing-out, linear rules of origin, and shorter sensitive lists.

The statistical evidence on the issue suggests that Sri Lanka's bilateral trade with India has grown and significantly diversified during the period under the ILFTA, although trade expansion slowed down in the second half of the last decade (2000-10). The country's bilateral trade with Pakistan has not, however, expanded or diversified very much. Sri Lanka's relatively high trade performance with India cannot be considered an exclusive product of the ILFTA, nor can the country's weaker trade performance with Pakistan be attributed to the PLFTA alone.

Unilateral trade liberalization in individual countries and the resulting shift in their production specialization and overall trade expansion have much to do with the changes that have occurred in Sri Lanka's bilateral trade with India and Pakistan. In addition to the notion of a "big market within proximity" dominating bilateral trade expansion with 
India, the overall economic connectivity beyond merchandise trade appears to favor Sri Lanka's bilateral trade expansion with India. However, both internal and external shocks as well as crucial policy changes in favor of domestic production and protection appear to have hindered potential bilateral trade expansion during the second half of the last decade.

Our analysis infers that the scope for bilateral free trade alone may not be an adequate condition for better trade performance-trade facilitation, greater connectivity, investment, and services trade are among the important elements of greater trade performance. Even bilateral FTAs could perform better under a low-tariff regime achieved through a unilateral liberalization process than under the FTAs that seek reciprocity and rules of origin. Therefore, greater trade liberalization and facilitation in the region is likely to enhance trade performance even under bilateral FTAs, while such an approach would minimize trade distortions by those FTAs that are implemented in high-protective regimes. 


\section{References}

Abeyratne, S. (2009). Economic and social impact of the global financial crisis in Sri Lanka. Colombo, Sri Lanka: UNDP Asia-Pacific Regional Centre.

Abeyratne, S. (2011, June). India as a source market for tourism industry of Sri Lanka: Too big to be ignored. Paper presented at a public seminar (Sanvada) of the Pathfinder Foundation, Colombo, Sri Lanka.

Abeyratne, S. (2012). Regional integration of Sri Lanka and its roadmap towards an economic union. Country paper submitted to Asian Development Bank, Kathmandu, Nepal.

Abeyratne, S., \& Ranasinghe, A. (2004). Sri Lanka's trade expansion during economic reform. In O. H. Chowdhury \& W. van der Geest (Eds.), Economic reform and trade performance in South Asia. Dhaka, Bangladesh: Bangladesh Institute of Development Studies.

Ahmed, S., Kelegama, S., \& Ghani, E. (Eds.). (2010). Promoting economic cooperation in South Asia: Beyond SAFTA. Washington, DC: World Bank.

Athukorala, P. (2011). Production networks and trade patterns in East Asia: Regionalization or globalization? Asian Economic Papers, 10(1), 65-95.

Banik, N., \& Gilbert, J. (2008). Regional integration and trade costs in South Asia (Working Paper No. 127). Tokyo, Japan: Asian Development Bank Institute. Retrieved from http://www.adbi.org/workingpaper/2008/12/19/2781.regional.integration.trade.costs.south.asia/

Behera, S. K., \& Mukherji, I. N. (2011, July). Indo-Sri Lanka free trade agreement: A decadal assessment. Paper presented at the Seminar on Strategic Partnership for Policy Development and Action to Foster Regional Cooperation in South Asia, Pathfinder Foundation and Asian Development Bank, Colombo, Sri Lanka.

Central Bank of Sri Lanka. (2011). Annual report 2011. Colombo, Sri Lanka: Author.

Federation of Indian Chambers of Commerce and Industry. (2011, September). South Asia Forum: Background paper. Paper presented at the South Asia Forum on Integration in South Asia: Moving Towards a South Asian Economic Union, New Delhi, India. 
India, Ministry of Tourism. (2011). India tourism statistics at a glance 2010. Retrieved from IndiaWeb.com: www.tourism.gov.in/

Krueger, A. O. (1997). Free trade agreements versus customs unions. Journal of Development Economics, 54(1), 169-187.

Pursell, G. (2011, June 18). Para-tariffs and Sri Lanka's new protectionism. Economic and Political Weekly, 46(25), 31-34.

Ratnayake, J. (2011). Future of Sri Lankan ports in the face of current port development saga in India (Mimeo). Colombo, Sri Lanka: Pathfinder Foundation.

South Asian Association for Regional Cooperation. (1999). SAARC vision beyond the year 2000: Report of the SAARC group of eminent persons. New Delhi, India: Shipra Publications.

Samarajiva, R., \& Herath, P. (2009, January). 1.2 trillion dollar GDP, 1.1 billion people: How best can we grow with India? Paper presented at a public seminar (Sanvada) of the Pathfinder Foundation, Colombo, Sri Lanka.

Sri Lanka, Customs Department. (n.d.). Customs tariff guide. Colombo, Sri Lanka: Author.

Sri Lanka, Tourism Development Authority. (2010). Annual statistical report of Sri Lanka tourism 2010. Colombo, Sri Lanka: Author. Retrieved from www.sltda.gov.lk/

Soz, S., \& Srivastava, R. N. (2010). SAARC emerging challenges: 25 years of $S A A R C$. New Delhi, India: Foundation for Peace and Sustainable Development.

Weerakoon, D. (2009). Bilateral FTAs in South Asia: Recasting the regionalism debate [Special edition]. Lahore Journal of Economics, 14, 155-170. 